\title{
Surveying industry needs for leadership in entry-level engineering positions
}

\section{Beth Lin Hartmann P.E., Iowa State University}

Beth L. Hartmann is a Lecturer of Construction Engineering at Iowa State University (ISU). A retired U.S. Navy Civil Engineer Corps officer (O-5), she currently teaches the design-build capstone course for civil and construction engineering students and the construction engineering learning community. Hartmann received her Bachelor of Art in Architecture and her Master or Science in Civil Engineering with an emphasis in Construction Engineering and Management from ISU in 1989 and 1996, respectively.

\section{Dr. Clinton Stephens, Iowa State University}

Dr. Clinton M. Stephens is a lecturer for leadership education with the Carrie Chapman Catt Center for Women and Politics at Iowa State University. Currently, Stephens coordinates the Catt Center's burgeoning leadership program and teaches classes in leadership development including CLPS 322, "Leadership Styles and Strategies in a Diverse Society."

Stephens continues his research and dissemination work that focuses on student leadership development, specifically assessing the effectiveness of courses and workshops to develop participants' leadership skills, directs the overall program and teaches the growing number of students in the program's core courses.

Stephens completed a B.S. in Business Administration at Kansas State University in 2002, a M.S. in College Student Development at Oklahoma State University in 2005 and a Ph.D. in Higher Education Administration in 2012 at Iowa State University.

\section{Dr. Charles T. Jahren P.E., Iowa State University}

BIOGRAPHY - Charles T. Jahren Charles T. Jahren is the W. A. Klinger Teaching Professor and the Assistant Chair for Construction Engineering in the Department of Civil, Construction and Environmental Engineering at Iowa State University. He earned his Bachelor of Science in Civil Engineering and his Master of Business Administration from the University of Minnesota and his $\mathrm{PhD}$ in Civil Engineering from Purdue University. He has over six years of industrial experience as a bridge construction project engineer for a construction contractor and as a research engineer for the Naval Civil Engineering Laboratory in Port Hueneme California. His teaching interests include construction equipment, cost estimating and construction process design. His research interests include highway and heavy construction methods, road maintenance methods, innovations in construction process administration, engineering education, hybrid learning and online learning. 


\title{
Surveying industry needs for leadership in entry-level engineering position
}

\begin{abstract}
Industry is expecting engineering students to graduate with both strong technical skills and strong leadership skills that they can apply in the companies they join. Recent research has demonstrated wide-ranging meanings with regard to how companies define leadership. Using qualitative research methods in an earlier study, we found that personnel from engineering companies involved with hiring define leadership by categorizing it into five main themes or competencies: initiative/confidence, communication, interpersonal interaction, teamwork, and engagement. This study extends the prior research by developing and validating a survey instrument based on these five themes. This paper presents the development and refinement of the survey instrument by utilizing fundamentals of survey methodology and cognitive interviews. The survey contributes to our understanding of the engineering industry's needs for leadership competencies in their new hires. The prior research effort involved interviews of human resources and engineering personnel at six engineering companies. During the next phase of our project, this survey will be distributed to over 800 engineering companies to expand our understanding of the industry's needs. Findings from this pilot survey will inform engineering educators about leadership competencies of which they should focus while better preparing our students for entry-level positions in engineering and aid in the further development of this instrument. The results of this research can inform the efforts of all engineering educators that strive to embed leadership development into the engineering courses. With this research, educators will know what expectations for leadership skills their students will encounter in their entry-level positions after graduation. Further, engineering programs will be able to better articulate the leadership skills their students are developing and educate potential employers on both the technical and leadership education their students are gaining in their courses. Finally, employers will benefit from hiring engineering graduates who are better prepared for the leadership expectations in the entry-level positions.
\end{abstract}

\section{Introduction}

The engineering industry continues to emphasize the importance of engineers entering the workforce to possess leadership skills. While some studies have been conducted to define what companies are looking for in future hires and/or what academic programs are doing to prepare undergraduates for industry, ${ }^{7,21,22,34}$ other work focused solely on leadership competencies and requirements. ${ }^{3,5,6,9,11,12,26,27}$ Our qualitative study conducted in summer 2014, found that personnel from engineering companies involved with hiring define leadership by categorizing various knowledge, abilities, and behaviors into five main leadership themes or competencies: initiative/confidence, communication, interpersonal interaction, teamwork, and engagement. It is our goal to understand what leadership means to industry and to develop coursework, instruction, and experiences that will best prepare our undergraduates for opportunities in engineering.

In this paper, we will describe the development of a survey instrument that will validate and expand the findings of our earlier project to define what employers mean when they use the word 
leadership as a requirement for applicants. Working with our five themes, or competencies, we created a survey instrument to determine the importance of each theme to employment in industry. The development of this survey will aid in our continued effort to understand the needs of industry and to shape engineering leadership curricula.

\section{Background}

The effort to emphasize the importance of leadership in engineering education has been enduring since the 1990s. Leadership has more recently been underscored in various engineering reports, including those by the National Academy of Engineering. ${ }^{18,19}$ Additionally, researchers have offered leadership skills are requisite for successful and impactful engineering careers. ${ }^{3,6,8,9,10 \text {, }}$ ${ }^{11,27}$ Although the evidence exists for the need of leadership development for engineering undergraduates, only 3 of the 28 engineering programs include the term leadership in their Program Criteria in ABET Criteria for 2014-2015. Those programs are (1) Civil, (2) Construction, and (3) Engineering Management and Similarly Named Engineering Programs. ${ }^{1}$

Due to the work and influence of the American Society of Civil Engineering (ASCE), civil engineering and construction engineering programs lead the effort with regard to explicit identification of the need for leadership in the ABET Program Criteria. As the governing body for the civil engineering and construction engineering, ASCE continues to highlight the need for civil engineers to possess technical and professional skills. In two key publications, The Vision for Civil Engineering in $2025^{2}$ and the second edition of the ASCE Body of Knowledge ${ }^{4}$, also known as BOK2, ASCE has offered strong rationale for the need of leadership development for civil engineers. ASCE recognized the global impacts of leadership by stating, "U.S. civil engineers can be catalysts in sharing the vision with the global civil engineering community." The report continues by outlining some key actions, including "a more robust educational path for civil engineers that prepares them for leadership and provides the multifaceted non-technical skills to serve on projects affecting the public good." ${ }^{2}$ The ASCE BOK2 categorizes twenty-four outcomes for entry into the civil engineering profession. ASCE organized the outcomes into three categories: (1) foundational, (2) technical, and (3) professional, as well as identified the level of proficiency desired at various points in one's career. Leadership (Outcome 20) was identified as a professional outcome requiring proficiency in "knowledge, comprehension, and application" at the undergraduate level. ${ }^{4}$

Researchers have reviewed the ABET (a) through (k) student outcomes, showing how leadership knowledge, values, attitudes, skills, and abilities may be embedded into these outcomes without the word leadership appearing in the ABET documents. ${ }^{6,7,11,21,26,34}$ Others have focused on identifying leadership competencies. ${ }^{20,28,29}$ While there is a clear effort to study and elevate the importance of leadership development, as well as infuse leadership instruction and activities into undergraduate engineering programs, Seemiller and Murray ${ }^{29}$ revealed that engineering programs contained the fewest "Student Leadership Competencies" of the 18 categories of academic programs they reviewed.

In concert with the desire to inculcate leadership in engineering programs, work to define the term engineering leadership has become more concentrated in the past five to six years. Graham, et al. ${ }^{12}$ identified, compared, and contrasted over 40 engineering leadership programs. Locating 
these programs and understanding how they are similar and different sparked a national conversation on this topic and served as the catalyst to bring together academic institutions to start meeting to share best practices. According to the Rice Center for Engineering Leadership ${ }^{24}$ this consortium of university engineering leadership programs, otherwise known as the Community of Practice for Engineering Leadership Education for $21^{\text {st }}$ Century Engineers (COMPLETE) has been meeting regularly since 2010. This body of like-minded educators and practitioners also played an instrumental role in the formation of the ASEE Leadership Division (LEAD). One of the goals of COMPLETE and the ASEE LEAD Division is to further research in this area.

\section{Purpose}

The purpose of the research project is to identify specific leadership competencies that applicants, specifically undergraduates, should possess when applying for full-time employment positions. The three-phase research uses mixed methods to answer this question. First, in-person interviews with college recruiters are conducted to explore their definition of leadership when listed in job descriptions. Second, the results of these interviews are synthesized and used to construct a survey for wider data collection from college recruiters. Third, it is expected that the survey results from more than 800 recipients will be analyzed to examine what leadership competencies that recruiters are seeking, and to disaggregate this understanding by the engineering field. This paper is a discussion of phase two, which includes the survey development process that will contribute a rigorous instrument to our field for identifying the specific leadership competencies undergraduates should possess upon graduation.

The study is being conducted at a large land-grant institution in the Midwest. The institution serves 35,000 students and employs 6,300 faculty and staff members. The College of Engineering contains 8 academic departments and offers 12 majors. The college hosts a large indoor career fair each semester, with approximately of 300 companies represented and 3,000 to 6,000 students and alumni in attendance each semester.

\section{Discussion}

\section{Phase One: Recruiter Interviews}

Phase one of this project was a qualitative study to interview college recruiters in an in-depth interview to discover what their respective company meant by the word leadership when explicitly used in a position description. Our research question was, "What do companies hiring full-time entry-level engineers mean by leadership when used in a job description?"

College recruiters were identified through a systematic approach to reviewing job posting information obtained from engineering career services personnel for the period of 1 August 2006 through 31 July 2013. A total of 16,173 jobs were posted in the university career database for all students and alumni in the college of engineering during the seven year period noted. Since our focus was on entry-level, full-time positions, the data was further analyzed to eliminate positions for internships, Co-ops, Master's/PhD students and alumni. Table 1 shows the 7,235 job descriptions that met our criteria by year posted, as well as those that included the word 
leadership. Overall, $982(13.6 \%)$ of the job postings contained the word leadership. ${ }^{14}$

Table $1 .^{14}$

\begin{tabular}{lccc}
\multicolumn{4}{l}{ Full-Time, Entry-Level Engineering Job Postings } \\
\hline Year & $\underline{\text { All }}$ & Leadership & $\underline{\%}$ \\
$2006-2007$ & 929 & 117 & 12.6 \\
$2007-2008$ & 920 & 119 & 12.9 \\
$2008-2009$ & 502 & 69 & 13.8 \\
$2009-2010$ & 405 & 49 & 12.1 \\
$2010-2011$ & 1,079 & 136 & 12.6 \\
$2011-2012$ & 1,555 & 212 & 13.6 \\
$2012-2013$ & 1,845 & 280 & 15.2 \\
Total & 7,235 & 982 & 13.6 \\
\hline
\end{tabular}

Further analysis was completed to identify potential participants. Possible participants were selected from companies with job postings targeting only construction engineering or electrical engineering graduates. Rationale for selecting these two engineering disciplines was to examine similarities and differences in one discipline with leadership explicitly included in the ABET Program Criteria (construction) and one that did not (electrical). Six recruiters from companies using leadership in one or more job descriptions participated in in-depth interviews. Data saturation was achieved for the intended purpose of identifying common themes. Information about the six participants is represented in Table $2 .{ }^{14}$

Table $2 .^{14}$

Industry Personnel Interviewed

\begin{tabular}{llc}
\hline $\begin{array}{l}\text { Industry } \\
\text { Gender }\end{array}$ & Job Title & $\begin{array}{c}\text { Years at } \\
\text { Company }\end{array}$ \\
\hline $\begin{array}{l}\text { Construction } \\
\text { Female }\end{array}$ & Human Resources Director & 9.0 \\
Female & Director of Learning and Development & 8.5 \\
Female & Human Resources Manager & 2.5 \\
Electrical & & \\
Male & Application Engineering Manager & 15.5 \\
Female & Human Resources Representative & 25.0 \\
Male & Manager of Substation Engineering & 15.5 \\
\hline
\end{tabular}

Using qualitative research and analysis methods, five leadership competencies emerged: initiative/confidence, communication, interpersonal interaction, teamwork, and engagement. ${ }^{14}$ These themes were further defined by identifying key words and phrases from the transcripts of the interviews. Abbreviated descriptions are included in Table 3. 
Table 3.

Leadership Themes with Definitions

\begin{tabular}{ll}
\hline Theme & Definition \\
\hline Initiative/confidence & $\begin{array}{l}\text { Stepping up, going the extra step, asking question, having } \\
\text { confidence and/or self-confidence. }\end{array}$ \\
Communication & $\begin{array}{l}\text { Possess excellent written, oral, non-verbal, and listening skills. } \\
\text { Interpersonal Interaction }\end{array}$ \\
$\begin{array}{l}\text { Having people skills and the ability to build relationships and } \\
\text { resolve conflicts. }\end{array}$ \\
Teamwork & Being a team player, collaborative, and a consensus builder. \\
Engagement & Involved in extracurricular and volunteer activities. \\
\hline
\end{tabular}

\section{Phase Two: Survey Instrument Development}

These emerged themes from the six in-depth interviews are the foundation for the questions in our survey instrument. This section highlights how the survey instrument was developed and refined using survey methodology and cognitive interviews.

\section{Question development}

Responses from the earlier qualitative study and research notes were analyzed to identify key words and phrases mentioned by the participants. Using the original analysis and theme mapping process, questions were developed to align with the five themes: initiative/confidence, communication, interpersonal interaction, teamwork, and engagement. A review of literature revealed a long history of many approaches to categorization of leadership competencies. ${ }^{10,15,16 \text {, }}$ $23,25,28,29,32$ After review of the prior research and the results of the in-depth interviews in phase one, Seemiller's taxonomy ${ }^{28,29}$ was selected as the best fit to discuss.

To assist with question development, a matrix was devised with dimensions of leadership competencies and Seemiller's classifications. ${ }^{28,29}$ During the question writing phase, it was realized that responses relating to Seemiller's "values" would not be useful due to limitations presented by these types of questions. It was noted that industry personnel might be presented with challenges when asked to respond about the beliefs of others. Questions were written to focus on the remaining three categories of Seemiller's taxonomy: knowledge, abilities, and behaviors. Four questions were drafted for each cell in the matrix. These questions were written for survey takers to rate various knowledge, abilities, and behaviors on a six-point Likert scale ${ }^{17}$ from "Very Important" to "Not Important at All." Questions were tagged with the alphanumeric codes shown in Table 4 to track the questions and responses during this process. 
Table 4.

Question Matrix

\begin{tabular}{lccc}
\hline Categories/Dimension & A. Knowledge & B. Abilities & Behaviors \\
\hline 1. Initiative/Confidence & $1 \mathrm{~A}$ & $1 \mathrm{~B}$ & $1 \mathrm{C}$ \\
2. Communication & $2 \mathrm{~A}$ & $2 \mathrm{~B}$ & $2 \mathrm{C}$ \\
3. Interpersonal Interaction & $3 \mathrm{~A}$ & $3 \mathrm{~B}$ & $3 \mathrm{C}$ \\
4. Teamwork & $4 \mathrm{~A}$ & $4 \mathrm{~B}$ & $4 \mathrm{C}$ \\
5. Engagement & $5 \mathrm{~A}$ & $5 \mathrm{~B}$ & $5 \mathrm{C}$ \\
\hline
\end{tabular}

\section{Cognitive interviews}

After developing 60 possible survey questions regarding competencies and 4 user questions, two college recruiters were identified to assist with improving the survey instrument. These participants were a project manager and project engineer from a larger heavy-construction contractor and a building contractor, respectively. The project manager had over ten years of experience as a recruiter for their company, while the project engineer had five years of experience. Participants provided consent to allow their interview to be audiotaped.

Utilizing the cognitive interview process the participants each performed a "think-aloud" interview while taking survey. ${ }^{13,30,31,33}$ Improvements noted in the first interview were implemented before the second interview was performed. Both participants read the survey on a computer, verbalized their thoughts, and recorded their answers. The participants were audiotaped for 30-40 minutes during this process. The cognitive interviews revealed a few mechanical issues with the electronic survey, as well as seven questions that were not clear. Through this process, content validity was addressed by reviewing the survey instrument from the perspective of the survey taker and obtaining information on how the survey could be improved, including wording, grammar, order of questions, and context.

\section{Results}

The survey development process for this instrument yielded a more clear and concise instrument to enable the research team to collect the most meaningful data. Through a systematic approach to crafting and refining questions, the research team revised the survey instrument and prepared the survey for release via Qualtrics Survey Software (version 2015).

The revised survey is included in Appendix I and will be distributed to over 800 recruiters from companies who have hired a new graduate from the large Midwestern university between 2008 and 2014. This survey will serve as a pilot instrument and will be further refined after responses are analyzed. Construct validity will be determined through post-hoc tests.

\section{Further Research}

The use of qualitative research and cognitive interviews to design a survey instrument has been described in the paper and provides systematic and methodical approach for designing a survey regarding the leadership outcome that employers desire for student who are graduating from engineering programs. The responses received from this questionnaire that will yield data to 
assist researchers at academic institutions to assess, refine, and develop curricula to best prepare undergraduate students for a successful career in industry. It is intended that the results from this pilot survey will serve as a starting point for creating an instrument for a broader audience.

The first author has released the survey to over 800 recipients who were identified with the help of the engineering career services unit of the previously mentioned Midwestern university. Collection and analysis of the data will occur in the spring and summer of 2015. Results of the survey will be analyzed using with both basic and more advanced statistical techniques, including student t-tests, ANOVAs, and multivariate regression.

\section{Conclusion}

Industry representatives continue to cite the need for leadership skills in new hires and this need has been acknowledged by academia, as evidenced by the number of formal and informal engineering leadership programs identified by Graham, et al. ${ }^{12}$ in 2009 . It will be desirable for these programs to know the relative importance of leadership competencies expected by recruiters as they develop and revise curricula for undergraduate and graduate engineering students. The creation, use, and modification of this survey instrument will help with the quest for knowledge regarding engineering leadership competencies. This important vein of inquiry is identifying the leadership competencies expected by recruiters hiring full-time, entry-level engineers.

\section{References}

1. ABET. (2013). Criteria for Accrediting Engineering Programs: Effective for reviews during the 20142015 accreditation cycle. Baltimore: ABET.

2. American Society of Civil Engineers (2007), The Vision for Civil Engineering in 2025.

3. Arethya, K. S. and Kalkhoff, Michael T. (2010). The Engineering Leadership Program: A cocurricular learning environment by and for students. Journal of STEM Education, Volume 11, Issue 3 and 4, 70-74.

4. ASCE, Civil Engineering Body of Knowledge for the 21st Century - Preparing the Civil Engineer for the Future, $2^{\text {nd }}$ Edition, 2008.

5. Bernard M. Gordon-MIT Engineering Leadership Program, Capabilities of Effective Engineering Leaders (June 2011). Version 3.6, Retrieved online from http://web.mit.edu/gordonelp/leadershipcapabilities.pdf.

6. Bowman, B., J. Farr, (2000), "Embedding Leadership in Civil Engineering Education", Journal of Professional Issues in Engineering Education and Practice, 126(1), 16-20.

7. Brumm, T. J., Hanneman, L.F., \& Mickelson, S. K. (2006). Assessing and Developing Program Outcomes through Workplace Competencies. International Journal of Engineering Education, 22 (1), 123-129.

8. Cox, M. F., Cekic, O., \& Adams, S. G. (2010). Developing Leadership Skills of Undergraduate Engineering Students: Perspectives from Engineering Faculty. Journal of STEM Education: Innovations and Research, 11(3), 22-33. 
9. Crumpton-Young, L., McCauley-Bush, P., Rabelo, L., Meza, K., Ferreras, A., Rodriguez, B., Millan, A., Miranda, D., \& Kelarestani, M. (2010). Engineering Leadership Development Programs a Look at What Is Needed and What Is Being Done. Journal of STEM Education: Innovations and Research, 11(3), 10-21.

10. Dugan, J. P., \& Haber, P. (2007). Examining the influences of formal leadership programs on student educational gains. Concepts and Connections, 15(3), 7-10.

11. Farr, J. V., Walesh, S. G., \& Forsythe, G. B. (1997). Leadership development for engineering managers. Journal of Management in Engineering, 13(4), 38.

12. Graham, R., Crawley, E., \& Mendelsohn, B. (2009). Engineering leadership education: A snapshot of international good practice. Bernard M. Gordon MIT Leadership Program, 2009.

13. Groves, R. M., Fowler Jr, F. J., Couper, M. P., Lepkowski, J. M., Singer, E., \& Tourangeau, R. (2004). Survey methodology. John Wiley \& Sons.

14. Hartmann, B., \& Jahrens, C. (2014). Industry needs for entry-level engineering positions. Manuscript submitted for publication.

15. Hemphill, J. K., \& Coons, A. E. (1957). Development of the leader behavior description questionnaire. In R. M. Stogdill \& A. E. Coons (Eds.), Leader Behavior: Its Description and Measurement (pp. 6-38). Columbus, OH: The Ohio State University Press.

16. Kouzes, J. M., \& Posner, B. Z. (1998). Student leadership practices inventory: Student workbook. San Francisco, CA: Jossey-Bass.

17. Likert, Rensis (1932). "A Technique for the Measurement of Attitudes". Archives of Psychology 140: 155.

18. National Academy of Engineering (NAE). (2004). The Engineer of 2020: Visions of engineering in the new century, Washington, DC: National Academies Press.

19. National Academy of Engineering (NAE). (2005). Educating the Engineer of 2020: Adapting engineering education to the new century, Washington, DC: National Academies Press.

20. Özgen, S., Sánchez-Galofré, O., Alabart, J. R., Medir, M., \& Giralt, F. (2013). Assessment of Engineering Students' Leadership Competencies. Leadership and Management in Engineering, 13(2), 65-75.

21. Passow, H. (2012). "Which ABET Competencies Do Engineering Graduates Find Most Important in their Work?" Journal of Engineering Education, 101(1), 95-118.

22. Phani, C.S. (2007, January 8). The top 60 soft skills at work. Retrieved September 8, 2013, from Redif News: http://www.rediff.com/getahead/2007/jan/08soft.htm.

23. Posner, B. Z. (2010). Psychometric Properties of The Student Leadership Practices Inventory Retrieved Sept. 15, 2010, from http://media.wiley.com/assets/2232/98/StudentLPIPsychometricProperties 2010.pdf.

24. Rice Center for Engineering Leadership (2014). About Complete. Retrieved January 15, 2015, from http://complete2014.org/complete-partners/.

25. Rost, J. C. (1991). Leadership for the twenty-first century. New York, NY: Praeger.

26. Schuhmann, R. J., Magarian, J. N., Huttner-Loan, E.(2014). A Method for Assessing Engineering Leadership Content in the Engineering Curriculum: A First Look at Civil Engineering Project Management Courses. 2014 ASEE Conference, June 2014. 
27. Schuhmann, R. J. (2010). Engineering Leadership Education -- The Search for Definition and a Curricular Approach. Journal of STEM Education: Innovations \& Research, 11(3/4), 61-69.

28. Seemiller, C. (2013). The Student Leadership Competencies Guidebook: Designing Intentional Leadership Learning and Development. John Wiley \& Sons.

29. Seemiller, C., \& Murray, T. (2013). The Common Language of Leadership. Journal of Leadership Studies, 7(1), 33-45. doi: 10.1002/jls.21277.

30. Tourangeau, R. (1984). Cognitive science and survey methods. Cognitive aspects of survey methodology: Building a bridge between disciplines, 73-100.

31. Tourangeau, R., Rips, L. J., \& Rasinski, K. (2000). The psychology of survey response. Cambridge University Press.

32. Tyree, T. (1998). Designing an instrument to measure socially responsible leadership using the social change model of leadership development. Dissertation Abstracts International, 59(06), 1945, (AAT 9836493).

33. Willis, G. B. (1999). Cognitive interviewing: a "how to" guide. Reducing Survey Error through Research on the Cognitive and Decision Processes in Surveys. In Meeting of the American Statistical Association.

34. Yaacoub, H. K., Husseini, F., \& Choueiki, Z. (2011). Engineering soft skills: a comparative study between the GCC area demands and the ABET requirements. Competition Forum, 9(1), 88. 


\section{Appendix I - Initial Survey Questions}

\section{Introduction}

Introduction Statement

Participation agreement

○ Agree

- Disagree

\section{Leadership Competency Questions}

How important are the following for an applicant to possess when applying for a full-time, entry-level engineering position with your company?

* Some of these questions may be similar to those you have already answered.

\begin{tabular}{|c|c|c|c|c|c|c|}
\hline & $\begin{array}{l}\text { Extremely } \\
\text { Important }\end{array}$ & $\begin{array}{c}\text { Very } \\
\text { Important }\end{array}$ & $\begin{array}{l}\text { Somewhat } \\
\text { Important }\end{array}$ & $\begin{array}{l}\text { Somewhat } \\
\text { Unimportant }\end{array}$ & $\begin{array}{c}\text { Very } \\
\text { Unimportant }\end{array}$ & $\begin{array}{l}\text { Not at all } \\
\text { Important }\end{array}$ \\
\hline Understand my company's products and services & $\square$ & $\square$ & $\square$ & $\square$ & $\square$ & $\square$ \\
\hline Have excellent writing skills & $\square$ & $\square$ & $\square$ & $\square$ & $\square$ & $\square$ \\
\hline Create positive rapport with others & $\square$ & $\square$ & $\square$ & $\square$ & $\square$ & $\square$ \\
\hline Know how to delegate & $\square$ & $\square$ & $\square$ & $\square$ & $\square$ & $\square$ \\
\hline Participated as a member of a student organization & $\square$ & $\square$ & $\square$ & $\square$ & $\square$ & $\square$ \\
\hline Be a self starter & $\square$ & $\square$ & $\square$ & $\square$ & $\square$ & $\square$ \\
\hline Demonstrate participation in volunteer service & $\square$ & $\square$ & $\square$ & $\square$ & $\square$ & $\square$ \\
\hline Interact positively with others on a team & $\square$ & $\square$ & $\square$ & $\square$ & $\square$ & $\square$ \\
\hline Conduct an effective meeting & $\square$ & $\square$ & $\square$ & $\square$ & $\square$ & $\square$ \\
\hline Well connected to others in the industry & $\square$ & $\square$ & $\square$ & $\square$ & $\square$ & $\square$ \\
\hline $\begin{array}{l}\text { Appreciates the benefits of being involved in } \\
\text { extracurricular activities }\end{array}$ & $\square$ & $\square$ & $\square$ & $\square$ & $\square$ & $\square$ \\
\hline Recognize that diversity is an asset & $\square$ & $\square$ & $\square$ & $\square$ & $\square$ & $\square$ \\
\hline $\begin{array}{l}\text { Have knowledge on how to deliver effective } \\
\text { feedback }\end{array}$ & $\square$ & $\square$ & $\square$ & $\square$ & $\square$ & $\square$ \\
\hline Demonstrate active listening skills & $\square$ & $\square$ & $\square$ & $\square$ & $\square$ & $\square$ \\
\hline $\begin{array}{l}\text { Display commitment to helping others in the } \\
\text { community }\end{array}$ & $\square$ & $\square$ & $\square$ & $\square$ & $\square$ & $\square$ \\
\hline Possess confidence & $\square$ & $\square$ & $\square$ & $\square$ & $\square$ & $\square$ \\
\hline $\begin{array}{l}\text { Have awareness about strategies to boost self } \\
\text { confidence }\end{array}$ & $\square$ & $\square$ & $\square$ & $\square$ & $\square$ & $\square$ \\
\hline Asks questions & $\square$ & $\square$ & $\square$ & $\square$ & $\square$ & $\square$ \\
\hline Build relationships & $\square$ & $\square$ & $\square$ & $\square$ & $\square$ & $\square$ \\
\hline Have knowledge about group dynamics & $\square$ & $\square$ & $\square$ & $\square$ & $\square$ & $\square$ \\
\hline Knowledgeable about my company & $\square$ & $\square$ & $\square$ & $\square$ & $\square$ & $\square$ \\
\hline Motivated to learn new things & $\square$ & $\square$ & $\square$ & $\square$ & $\square$ & $\square$ \\
\hline Know how to write a professional email & $\square$ & $\square$ & $\square$ & $\square$ & $\square$ & $\square$ \\
\hline Have knowledge about active listening techniques & $\square$ & $\square$ & $\square$ & $\square$ & $\square$ & $\square$ \\
\hline Engage effectively in difficult conversations & $\square$ & $\square$ & $\square$ & $\square$ & $\square$ & $\square$ \\
\hline Be cooperative with team members & $\square$ & $\square$ & $\square$ & $\square$ & $\square$ & $\square$ \\
\hline Participated in community service activities & $\square$ & $\square$ & $\square$ & $\square$ & $\square$ & $\square$ \\
\hline Know how to treat others with respect & $\square$ & $\square$ & $\square$ & $\square$ & $\square$ & $\square$ \\
\hline Motivated to step up & $\square$ & $\square$ & $\square$ & $\square$ & $\square$ & $\square$ \\
\hline Able to resolve a conflict & $\square$ & $\square$ & $\square$ & $\square$ & $\square$ & $\square$ \\
\hline
\end{tabular}


How important are the following for an applicant to possess when applying for a full-time, entry-level engineering position with your company?

* Some of these questions may be similar to those you have already answered.

\begin{tabular}{|c|c|c|c|c|c|c|}
\hline & $\begin{array}{l}\text { Extremely } \\
\text { Important }\end{array}$ & $\begin{array}{c}\text { Very } \\
\text { Important }\end{array}$ & $\begin{array}{l}\text { Somewhat } \\
\text { Important }\end{array}$ & $\begin{array}{l}\text { Somewhat } \\
\text { Unimportant }\end{array}$ & $\begin{array}{c}\text { Very } \\
\text { Unimportant }\end{array}$ & $\begin{array}{l}\text { Not at all } \\
\text { Important }\end{array}$ \\
\hline Provide constructive feedback to others & $\square$ & $\square$ & $\square$ & $\square$ & $\square$ & $\square$ \\
\hline Have received training in teamwork & $\square$ & $\square$ & $\square$ & $\square$ & $\square$ & $\square$ \\
\hline Inspire others & $\square$ & $\square$ & $\square$ & $\square$ & $\square$ & $\square$ \\
\hline Performed community service & $\square$ & $\square$ & $\square$ & $\square$ & $\square$ & $\square$ \\
\hline Shows commitment to the team & $\square$ & $\square$ & $\square$ & $\square$ & $\square$ & $\square$ \\
\hline $\begin{array}{l}\text { Have knowledge about "self" to enhance self } \\
\text { confidence }\end{array}$ & $\square$ & $\square$ & $\square$ & $\square$ & $\square$ & $\square$ \\
\hline Know how to prepare an effective presentation & $\square$ & $\square$ & $\square$ & $\square$ & $\square$ & $\square$ \\
\hline Maintain eye contact during a conversation & $\square$ & $\square$ & $\square$ & $\square$ & $\square$ & $\square$ \\
\hline $\begin{array}{l}\text { Represent a colleagues' position when they are } \\
\text { not present }\end{array}$ & $\square$ & $\square$ & $\square$ & $\square$ & $\square$ & $\square$ \\
\hline $\begin{array}{l}\text { Demonstrate a successful event they have } \\
\text { planned }\end{array}$ & $\square$ & $\square$ & $\square$ & $\square$ & $\square$ & $\square$ \\
\hline Influence others & $\square$ & $\square$ & $\square$ & $\square$ & $\square$ & $\square$ \\
\hline Go above and beyond what is asked & $\square$ & $\square$ & $\square$ & $\square$ & $\square$ & $\square$ \\
\hline Communicate effectively with clients & $\square$ & $\square$ & $\square$ & $\square$ & $\square$ & $\square$ \\
\hline $\begin{array}{l}\text { Understand the roles and responsibilities of others } \\
\text { on the team }\end{array}$ & $\square$ & $\square$ & $\square$ & $\square$ & $\square$ & $\square$ \\
\hline $\begin{array}{l}\text { Performed successfully as a cabinet member of a } \\
\text { student organization }\end{array}$ & $\square$ & $\square$ & $\square$ & $\square$ & $\square$ & $\square$ \\
\hline Understand they should collaborate with others & $\square$ & $\square$ & $\square$ & $\square$ & $\square$ & $\square$ \\
\hline $\begin{array}{l}\text { Able to facilitate a discussion where there are } \\
\text { differing opinions }\end{array}$ & $\square$ & $\square$ & $\square$ & $\square$ & $\square$ & $\square$ \\
\hline Know how to write a memo & $\square$ & $\square$ & $\square$ & $\square$ & $\square$ & $\square$ \\
\hline Connects with others & $\square$ & $\square$ & $\square$ & $\square$ & $\square$ & $\square$ \\
\hline $\begin{array}{l}\text { Demonstrates knowledge about the benefits of } \\
\text { participating in volunteer service }\end{array}$ & $\square$ & $\square$ & $\square$ & $\square$ & $\square$ & $\square$ \\
\hline Motivated to understand others' circumstances & $\square$ & $\square$ & $\square$ & $\square$ & $\square$ & $\square$ \\
\hline $\begin{array}{l}\text { Know the importance of being involved in activities } \\
\text { outside of the classroom }\end{array}$ & $\square$ & $\square$ & $\square$ & $\square$ & $\square$ & $\square$ \\
\hline $\begin{array}{l}\text { Share an example of a time they have served on a } \\
\text { team and delegated successfully }\end{array}$ & $\square$ & $\square$ & $\square$ & $\square$ & $\square$ & $\square$ \\
\hline Be empathetic towards others on the team & $\square$ & $\square$ & $\square$ & $\square$ & $\square$ & $\square$ \\
\hline Takes the initiative & $\square$ & $\square$ & $\square$ & $\square$ & $\square$ & $\square$ \\
\hline $\begin{array}{l}\text { Display success as a leader of a student } \\
\text { organization }\end{array}$ & $\square$ & $\square$ & $\square$ & $\square$ & $\square$ & $\square$ \\
\hline $\begin{array}{l}\text { Demonstrate knowledge of the value of getting } \\
\text { involved with professional organizations }\end{array}$ & $\square$ & $\square$ & $\square$ & $\square$ & $\square$ & $\square$ \\
\hline Knows how to positively interact with others & $\square$ & $\square$ & $\square$ & $\square$ & $\square$ & $\square$ \\
\hline Demonstrate excellent oral presentation skills & $\square$ & $\square$ & $\square$ & $\square$ & $\square$ & $\square$ \\
\hline Willing to ask for help & $\square$ & $\square$ & $\square$ & $\square$ & $\square$ & $\square$ \\
\hline
\end{tabular}

\section{User Questions}

What is your job title?

How long have you worked with your current company?
$\circ \quad$ Less than 1 year
- 2-5 years
- 6-10 years
o More than 10 years 
My company hires students from the following engineering programs (select all that apply):

- Aerospace

- Agricultural

- Biological Systems

- Chemical and Biological

- Civil/Environmental

○ Computer

- Construction

- Electrical

$\circ \quad$ Industrial and Manufacturing Systems

- Materials

- Mechanical

- Software

The last time my company attended the [University] Engineering Career Fair was:

○ Spring 2015

- Fall 2014

- Spring 2014

- Over one year ago

- Over two years ago

- Over three years ago

- Never

- I don't know (excluded from analysis)

Thank you for participation in this study. 